\title{
Molecular and Metabolic Mechanisms Underlying Selective 5-Aminolevulinic Acid-Induced Fluorescence in Gliomas
}

\author{
Jeffrey I. Traylor ${ }^{1,+} \mathbb{D}$, Mark N. Pernik ${ }^{1,+} \mathbb{D}$, Alex C. Sternisha ${ }^{2}$, Samuel K. McBrayer ${ }^{2, *}$ and Kalil G. Abdullah $^{1, *}$ \\ 1 Department of Neurological Surgery, University of Texas Southwestern Medical Center, Dallas, \\ TX 75235, USA; jeffrey.traylor@utsouthwestern.edu (J.I.T.); mark.pernik@utsouthwestern.edu (M.N.P.) \\ 2 Children's Medical Center Research Institute, University of Texas Southwestern Medical Center, Dallas, \\ TX 75390, USA; alex.sternisha@utsouthwestern.edu \\ * Correspondence: samuel.mcbrayer@utsouthwestern.edu (S.K.M.); kalil.abdullah@utsouthwestern.edu \\ (K.G.A.); Tel.: +1-(214)-648-3730 (S.K.M.); +1-(214)-645-2300 (K.G.A.) \\ + These authors contributed equally to this work.
}

Citation: Traylor, J.I.; Pernik, M.N.; Sternisha, A.C.; McBrayer, S.K.; Abdullah, K.G. Molecular and Metabolic Mechanisms Underlying Selective 5-Aminolevulinic Acid-Induced Fluorescence in Gliomas. Cancers 2021, 13, 580. https://doi.org/10.3390/cancers 13030580

Received: 4 January 2021

Accepted: 26 January 2021

Published: 2 February 2021

Publisher's Note: MDPI stays neutral with regard to jurisdictional claims in published maps and institutional affiliations.

Copyright: (C) 2021 by the authors Licensee MDPI, Basel, Switzerland. This article is an open access article distributed under the terms and conditions of the Creative Commons Attribution (CC BY) license (https:// creativecommons.org/licenses/by/ $4.0 /)$.
Simple Summary: 5-aminolevulinic acid (5-ALA) is a medication that produces fluorescence in certain cancers, which enables surgeons to visualize tumor margins during surgery. Gliomas are brain tumors that can be difficult to fully resect due to their infiltrative nature. In this review we explored what is known about the mechanism of 5-ALA, recent discoveries that increase our understanding of that mechanism, and potential targets to increase fluorescence in lower grade gliomas.

\begin{abstract}
ALA) is a porphyrin precursor in the heme synthesis pathway. When supplied exogenously, certain cancers consume 5-ALA and convert it to the fluorogenic metabolite protoporphyrin IX (PpIX), causing tumor-specific tissue fluorescence. Preoperative administration of 5-ALA is used to aid neurosurgical resection of high-grade gliomas such as glioblastoma, allowing for increased extent of resection and progression free survival for these patients. A subset of gliomas, especially low-grade tumors, do not accumulate PpIX intracellularly or readily fluoresce upon 5-ALA administration, making gross total resection difficult to achieve in diffuse lesions. We review existing literature on 5-ALA metabolism and PpIX accumulation to explore potential mechanisms of 5-ALA-induced glioma tissue fluorescence. Targeting the heme synthesis pathway and understanding its dysregulation in malignant tissues could aid the development of adjunct therapies to increase intraoperative fluorescence after 5-ALA treatment.
\end{abstract}

Keywords: 5-ALA; high-grade glioma; low-grade glioma; intraoperative fluorescence; protoporphyrin IX

\section{Introduction}

Glioma is the most common primary malignancy of the central nervous system and is classified as grades I-IV by the World Health Organization (WHO). In general, grade I and II gliomas are considered "low-grade" (LGG) and comprise astrocytoma (pilocytic and diffuse subtypes) and oligodendrogliomas, while grade III and IV lesions, including anaplastic astrocytoma and glioblastoma (GBM), are considered "high-grade" (HGG) [1] Generally, LGG is less aggressive and confers a better overall prognosis. However, virtually all LGG tumors progress to HGG and eventually GBM which confers a particularly poor outcome. Despite resection with adjuvant chemoradiation having been shown to improve survival in patients with GBM, median survival is still approximately 14 months from the time of diagnosis [2]. Since care was standardized to adjuvant temozolomide and radiation 15 years ago, little progress has been made in improving the prognosis of glioma patients. However, several prognostic factors have been identified that have led to more accurate risk stratification. The relationship between extent of resection (EOR) and survival is one such prognostic factor that is becoming increasingly evident. Specifically, maximum 
resection of the contrast-enhancing portion of high-grade tumors confers longer overall survival [3-7]. Moreover, there is emerging evidence to suggest that even supra-total resection of regions beyond the contrast-enhancing margin may confer a survival benefit in GBM, further underscoring the importance of EOR in HGG [8]. The same relationship has been elucidated for LGG, although this is defined by mostly retrospective evidence $[9,10]$.

A hallmark of low- and high-grade glioma alike is the propensity to infiltrate into surrounding tissue [11]. Unlike central nervous system (CNS) metastases which are generally well circumscribed and exert a mass effect on adjacent neurovascular structures, glioma invades and disrupts this anatomy, making en bloc gross total resection challenging. In HGG cases, attempts are made to resect the contrast-enhancing margin corresponding to contrast-enhancement on magnetic resonance imaging (MRI). Stereotactic navigation can be used to ensure that the resection margin extends to this contrast-enhancing border on preoperative imaging.

As visualizing the tumor margins for infiltrating regions of glioma in the operating room is difficult, techniques for intraoperative fluorescence have emerged to improve EOR in this patient population. 5-aminolevulinic acid (5-ALA) is the most prominent and well-studied of these and has been shown to increase EOR and progression-free survival in malignant glioma based on the results of a 2006 phase III trial [5]. The authors of this trial ultimately concluded that 5-ALA enabled more complete resection of the contrast-enhancing tumor. Of note, tumors with substantial non-contrast-enhancing regions, consistent with LGG, were excluded from analysis due to poor fluorescent response to 5-ALA administration. In fact, only 10-20\% of LGG exhibited visible fluorescence with 5-ALA, making EOR in this patient population challenging [12,13]. Additionally, the use of 5-ALA has been associated with sporadic but not consistent fluorescence in some oncologic subtypes during resection, including metastatic lesions and lymphoma [14-17]. This indicates that in contrast to both LGG and other cranial tumors, the uniform and robust fluorescence found in high-grade gliomas represents a distinct and specific biological mechanism. In this systematic review, we discuss the underlying molecular mechanisms for 5-ALA fluorescence in glioma and summarize previous attempts at targeting these mechanisms with pharmacologic supplementation and photodynamic therapy. This review was conducted in accordance with the preferred reporting items for systematic reviews and meta-analyses (PRISMA) statement [18].

\section{5-ALA Development and History}

5-ALA is a non-proteinogenic amino acid formed through the condensation of succinyl$\mathrm{CoA}$ and glycine that serves as a metabolic precursor for heme biosynthesis. In cells, 5-ALA is converted to protoporphyrin IX (PpIX), a photosensitizer and direct precursor to hemoglobin in the heme synthesis pathway. As a photosensitizer, PpIX is excited by light between $\lambda=405$ (violet) and $\lambda=633 \mathrm{~nm}$ (red) [19]. The pathway for 5-ALA uptake and conversion to PpIX is outlined in Figure 1. Following initial discovery and synthesis of 5-ALA, it was tested for the diagnosis and treatment of skin, gastrointestinal, and bladder cancers, where it aided in disease recognition, excision, and photosensitizing treatment [20-23]. In 1998, Stummer and colleagues first described their results using oral 5-ALA to enhance intraoperative fluorescence of HGG which displayed high sensitivity, specificity, and accuracy for malignant cells [24]. Notably, their sentinel manuscript reported a lack of fluorescence in one patient with an LGG [24]. 


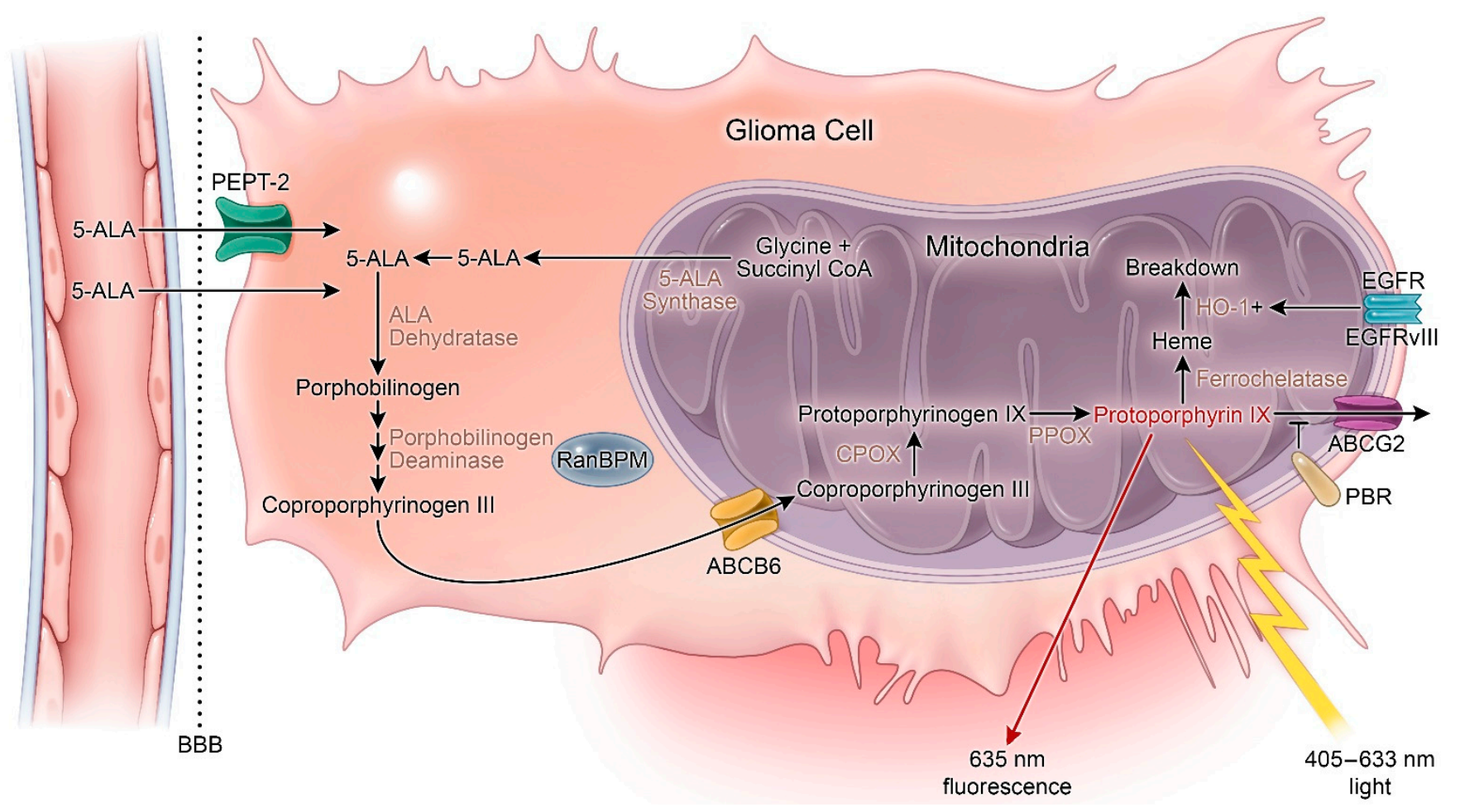

Figure 1. Heme synthesis pathway and mechanism of 5-aminolevulinic acid (5-ALA) fluorescence. 5-ALA: 5-aminolevulinic acid; ABCG2: ATP-binding cassette G2; ABCB6: ATP-binding cassette B6; BBB: Blood-brain barrier; CPOX: Coproporphyrinogen oxidase; HO-1: Heme-oxygenase 1; PBR: Peripheral benzodiazepine receptor; PPOX: Protoporphyrinogen oxidase. $+=$ increased activity.

To build on this discovery, Stummer and colleagues went on to conduct a randomized phase III trial. They concluded that intraoperative use of 5-ALA in HGG was safe and markedly increased complete resection rates (65\% in 5-ALA vs. $36 \%$ control). However, their study was underpowered to detect a difference in overall survival $[5,25]$. Based on these findings, the European Medicines Agency approved the use of 5-ALA in 2007. However, the United States Food and Drug Administration (FDA) approval took significantly longer due to their view of 5-ALA as a therapeutic rather than an adjunct tool to aid intraoperative visualization [26]. After the approval of an orphan drug application and the publication of other trials that highlighted the utility of 5-ALA in improving sensitivity and specificity of tumor margin discrimination during HGG resection, as well as progressionfree survival at 6 months, the drug was approved for use in WHO grades III or IV by the FDA in 2017 [13,25,27-29].

5-ALA is the most studied of the photosensitizing agents in glioma and possesses many desirable properties for intraoperative tumor tissue discrimination. First, it is rapidly eliminated, reducing risk of skin sensitivity [30]. Indeed, early studies of 5-ALA metabolism demonstrated that approximately $80 \%$ of the substance was excreted in $24 \mathrm{~h}$ compared to ${ }^{15} \mathrm{~N}$-labeled L- $\alpha$-amino acids in rats [31]. Second, 5-ALA is readily bioavailable following treatment with oral formulations. In patients undergoing cranial surgery, patients are administered 5-ALA as a well-tolerated oral liquid $2-4 \mathrm{~h}$ before craniotomy. Third, 5ALA accumulates in very few normal tissues (including mucosa of gastrointestinal tract, salivary glands, bile ducts, and seminal vesicles), thereby contributing to high signal to noise characteristics for tumor tissue visualization applications [22,32]. Fourth, 5-ALA is an endogenous human metabolite that is synthesized naturally from succinyl-CoA and glycine in the mitochondria; therefore, 5-ALA treatment is not associated with toxic side effects associated with administration of many xenobiotics. Taken together, these properties cooperate to render 5-ALA a valuable adjunct to neurosurgical HGG resection [33]. 


\section{Mechanism of 5-ALA Fluorescence}

In normal cells, succinyl-CoA and glycine undergo condensation by 5-ALA synthase to form 5-ALA. 5-ALA is then converted through a series of enzymatic steps to PpIX and, ultimately, to heme. This process is regulated by free iron and heme. PpIX accumulation in the cell can result from (1) increased 5-ALA levels, (2) 5-ALA synthase hyperactivity, or (3) dysfunction of the ferrochelatase (FECH) enzyme that produces heme from PpIX [34]. Impaired tumoral FECH activity is one potential explanation for the specificity of PpIX accumulation in tumor tissues following 5-ALA treatment. Indeed, FECH has been shown to be decreased in colon carcinoma liver metastases compared to liver parenchyma in rat models following 5-ALA administration. Similar results were also reported in prostate cancer, bladder cancer, and colonic cells [35-37].

Porphobilinogen deaminase (PBGD) is another enzyme in the heme-synthesis pathway that promotes PpIX production. Increased levels of PpIX corresponding to increased activity of PBGD as well as ALA dehydratase and uroporphyrinogen decarboxylase have been reported in human breast carcinoma cells [38]. Similar results have been reported for squamous cell carcinoma and adenocarcinoma [39]. Additional evidence indicates that the feedback mechanism between PBGD and ALA dehydratase may play a central role in PpIX synthesis [40]. In 2002, Greenbaum et al. described a significant subcellular localization of PBGD in the nucleus that rapidly decreased following stimulation of $\mathrm{C} 6$ glioma cell differentiation [41,42]. The authors concluded that PBGD may have a unique nuclear function in glioma cells. One year later, these investigators identified the nuclear Ran-binding protein RanBPM as an interacting partner of PBGD [43]. They further concluded that nuclear localization of PBGD in glioma may be related to the process of malignant transformation in glioma. Although these results implicate altered activity of heme biosynthesis pathway enzymes as a general cause of 5-ALA-induced PpIX accumulation in malignant tissue, the mechanistic underpinning of this phenotype specifically relevant in HGG is an area of intense investigation.

Coproporphyrinogen oxidase (CPOX) is an enzyme of the heme synthesis pathway that generates protoporphyrinogen III (a direct precursor from PpIX) from coproporphyrinogen III via oxidative decarboxylation. Expression of this enzyme has been shown to directly correlate with PpIX fluorescence in human glioma cells [44].

In the setting of GBM, FECH expression has been shown to be reduced relative to normal brain tissue, leading to accumulation of PpIX. Importantly, FECH silencing via RNA interference is sufficient to promote this phenotype, thereby providing evidence of a functional connection between FECH repression and 5-ALA-induced PpIX accumulation in GBM [45]. Similar results linking PpIX accumulation and decreased FECH activity have been shown in medulloblastoma cell lines [46]. In addition to regulation at the level of gene expression, $\mathrm{FECH}$ can also be repressed by iron chelation. Reduced intracellular iron content blocks FECH activity and triggers PpIX accumulation in human adenocarcinoma and hamster lung fibroblast cell lines [47-50]. Differentiation therapy targets another enzyme, coproporphyrinogen oxidase, in the heme synthesis pathway, leading to increased PpIX concentration in prostate cancer cells [51]. Unfortunately, no differentiation therapies exist for malignant gliomas as these tumors are known to have a partial and abnormal potential for differentiation [52].

\section{Metabolic Activity}

Further insight into the mechanism of 5-ALA fluorescence has been elucidated through studies of heme metabolism and its link to the tricarboxylic acid (TCA) cycle. Differential fluorescence upon 5-ALA treatment was observed in the IDH1 ${ }^{\mathrm{R} 132 \mathrm{H}}$ mutant compared to IDH1 wild-type (WT) WHO grade III gliomas. In IDH1 ${ }^{\mathrm{R} 132 \mathrm{H}}$ gliomas, the metabolite R-2hydroxyglutarate (2-HG) accumulates, leading to cellular reprogramming and oncogenesis. The observation in gliomas was further explored in U87MG-IDH1 ${ }^{\mathrm{R} 132 \mathrm{H}}$ cells in comparison to U87MG-IDH $1^{\text {WT }}$ cells, where U87MG- IDH1 ${ }^{\text {R132H }}$ cell metabolism of 5-ALA to PpIX was delayed in contrast to U87MG- IDH1 ${ }^{\mathrm{WT}}$ cells. As TCA cycle metabolites are involved 
in the generation of 5-ALA and thus PpIX, an exploration of the metabolic events that underlie the differences in 5-ALA mediated fluorescence was explored [53].

Upon 5-ALA treatment in U87MG-IDH1 ${ }^{\mathrm{R} 132 \mathrm{H}}$ cells, citrate and 2-HG concentrations were significantly increased, while $\alpha$-ketoglutarate $(\alpha-K G)$ decreased relative to U87MG$\mathrm{IDH} 1^{\mathrm{WT}}$ cells. From these data, Kim et al. reviewed the interconnectedness of the TCA cycle and the heme biosynthesis pathway and hypothesized that nicotinamide adenine dinucleotide phosphate (NADPH)-dependent heme degradation is impaired, based on knowledge that the IDH1 ${ }^{\mathrm{R} 132 \mathrm{H}}$ mutation perturbs NADPH homeostasis [53,54]. Specifically, this mutation abrogates WT activity of the IDH1 enzyme, thereby blocking NADPH synthesis associated with the oxidative decarboxylation of isocitrate to $\alpha-K G$. Furthermore, the IDH1 $1^{\mathrm{R} 132 \mathrm{H}}$ oncoprotein consumes NAPDH in the process of producing 2-HG [55]. Reduced levels of NADPH in IDH-mutated glioma cells has been proposed to contribute to PpIX accumulation [53]. Although this study highlighted metabolic alterations that lead to variance in 5-ALA-mediated fluorescence in IDH-mutated glioma cells, it is still not clear how IDH mutations influence glioma tissue fluorescence following 5-ALA treatment in the clinical setting. In particular, the simultaneous high prevalence of IDH mutations and low 5-ALA-induced tissue fluorescence associated with LGGs appear to be in conflict with the thesis that mutant IDH action stimulates PpIX content in glioma.

This conflict notwithstanding, there is additional evidence that NADPH production capacity may influence 5-ALA fluorescence due to crosstalk between the TCA cycle and heme synthesis pathway. Kim et al. conducted an RNA-sequencing study to compare GBM types classified by 5-ALA fluorescence [56]. This group identified glutaminase 2 as a regulator of 5-ALA fluorescence and confirmed this role in functional in vitro assays. Reduced expression of glutaminase 2 was associated with decreased production of NADPH and increased levels of PpIX and reactive oxygen species (ROS) in regions of GBM tumors with high fluorescence [56].

Lastly, lentiviral shRNA-mediated silencing of the heme biosynthesis enzymes in breast cancer cells was explored to better understand the pathway's role in 5-ALA fluorescence. Porphobilinogen synthase (PBGS) and porphobilinogen deaminase are involved in the production of PpIX, whereas FECH degrades PpIX. Silencing of PBGS and PBGD led to decreased 5-ALA-mediated fluorescence and decreased sensitivity to photodynamic therapy (PDT), whereas silencing of FECH led to the opposite effects on fluorescence and PDT sensitivity [57].

\subsection{Membrane Transport}

Uptake of exogeneous 5-ALA via active transport is cell-specific and provides negative feedback to 5-ALA synthase and accumulation of PpIX in the cell. PpIX efflux from the cell has also been studied and shown to be dependent on several factors. PpIX is synthesized in the mitochondria but quickly transports to the cytosol [58]. The mitochondrial peripheral benzodiazepine receptor (PBR) is one possible mechanism that has been shown to contribute to PpIX accumulation. In one study, PpIX concentration diminished with the administration of a competitive peripheral benzodiazepine receptor blockade concurrently with 5-ALA [59]. Another study showed that induction of PBR in glioma cell lines caused corresponding increases in intracellular PpIX concentration [60]. ATP-binding cassette transporter G2 (ABCG2) is another transporter that has been studied in the context of PpIX, with an inverse correlation between transporter expression and 5-ALA accumulation, although ABCG2 may be differentially expressed in GBM [58,61,62]. Further, cadherin 13 has been reported as a potential regulator of ABCG2 and PEPT1 expression and, accordingly, PpIX accumulation in glioma cells [45]. Overexpression of another ATP-binding cassette transporter known to regulate porphyrin synthesis, $\mathrm{ABCB6}$, has also been shown to increase PpIX accumulation in glioma cell lines and subsequently increase PDT effects [63]. Epidermal growth factor receptor (EGFR) and EGFRvIII co-expression has been shown to influence 5-ALA fluorescence in GBM [64]. Additionally, PpIX efflux out of the cell was reported in the presence of fetal bovine serum [65]. 
It is estimated that up to $20 \%$ of LGG will have macroscopic fluorescence after 5-ALA administration [12]. As pointed out by Collaud et al., the slowest step between 5-ALA uptake and formation of PpIX must be faster than the conversion of PpIX to heme in order for PpIX to accumulate and significant fluorescence to occur [66]. The variables that lead to 5-ALA-induced PpIX accumulation in target tissue are numerous and include bloodbrain barrier (BBB) integrity, expression of membrane transporters and heme biosynthesis pathway enzymes, as well as tissue environmental factors (temperature, $\mathrm{pH}$, etc.) which are reviewed in Table 1.

Table 1. Potential therapeutic targets in the 5-ALA fluorescence pathway.

\begin{tabular}{|c|c|c|}
\hline Potential Target & Supporting Literature & Findings \\
\hline \multirow{6}{*}{ Blood-brain barrier } & Novotny et al., 2000 [67] & $\begin{array}{l}\text { 5-ALA uptake into the choroid plexus occurs via a low } \mathrm{pH} \text {-dependent uptake by } \\
\text { PEPT2, and possibly a separate putative Na and HCO3-dependent mechanism }\end{array}$ \\
\hline & Utsuki et al., 2006 [68] & $\begin{array}{l}\text { Small, but detectable accumulations of PpIX were found in cellular boundaries of } \\
\text { diffuse astrocytoma treated with 5-ALA using laser spectroscopy intraoperatively }\end{array}$ \\
\hline & $\begin{array}{l}\text { Ennis et al., } 2003 \text { [69]; } \\
\text { Garcia et al., } 1998 \text { [70]; } \\
\text { Malakoutikhah et al., 2010 } \\
\text { [71]; Terr et al., } 1983 \text { [72] }\end{array}$ & The intact BBB is relatively impermeable to 5-ALA \\
\hline & Olivo and Wilson, 2004 [73] & $\begin{array}{l}\text { 5-ALA can weakly penetrate the intact BBB leading to PpIX accumulation, but at } \\
\text { markedly lower concentrations than areas without BBB such as circumventricular } \\
\text { regions; PpIX accumulation is higher around tumor and inflamed brain tissue }\end{array}$ \\
\hline & Molina et al., 2013 [74] & $\begin{array}{l}\text { Aquaporin-4 expression was higher in fluorescent gliomas and metastatic tissues } \\
\text { compared to non-fluorescent tissues }\end{array}$ \\
\hline & Fukuda et al., 1992 [75] & $\begin{array}{c}\text { Liposome encapsulated ALA administration in a mouse tumor model led to greater } \\
\text { porphyrin accumulation compared to free ALA }\end{array}$ \\
\hline \multicolumn{3}{|l|}{ Membrane transporters } \\
\hline ABCB6 & Zhao et al., 2013 [63] & $\begin{array}{l}\text { ABCB6 expression was elevated in human glioma cell lines which correlated with an } \\
\text { increase in intracellular PpIX accumulation }\end{array}$ \\
\hline \multirow{3}{*}{ ABCG2 } & Kawai et al., 2019 [62] & $\begin{array}{l}\text { ABCG2 expression was inversely related to 5-ALA positive staining in various } \\
\text { non-CNS cancer cell lines; knockdown and inhibition of ABCG2 lead to increased } \\
\text { 5-ALA cell staining }\end{array}$ \\
\hline & Ogino et al., 2011 [58] & $\begin{array}{l}\text { ABCG2 mediates PpIX cellular efflux and prevents PpIX in select cancer cells; } \\
\text { inhibition of ABCG2 increased PpIX accumulation }\end{array}$ \\
\hline & Oberstadt et al., 2013 [61] & ABCG2 is variably expressed in GBM \\
\hline \multirow{2}{*}{$\begin{array}{l}\text { Peripheral benzodiazepine } \\
\text { receptor (PBR) }\end{array}$} & Mesenholler et al., 2000 [59] & $\begin{array}{l}\text { Competitive inhibition of the mitochondrial PBR lead to decreased PpIX } \\
\text { accumulation in the mitochondria in a pancreatoma cell line; the PRB plays a role in } \\
\text { PpIX translocation out of the mitochondrial membrane }\end{array}$ \\
\hline & Bisland et al., 2007 [60] & $\begin{array}{l}\text { Induction of PBR in glioma cell lines with low-level light treatment increased PpIX } \\
\text { accumulation in cells }\end{array}$ \\
\hline $\begin{array}{l}\text { Epidermal growth factor } \\
\text { receptor (EGFR) }\end{array}$ & Fontana et al., 2017 [64] & $\begin{array}{l}\text { Co-expression of EGFR and EGFRvIII in GBM cell lines lead to activation of } \\
\text { heme-oxygenase } 1 \text { (HO-1) and reduced cell fluorescence; inhibition of HO-1 restored } \\
\text { fluorescence }\end{array}$ \\
\hline \multicolumn{3}{|l|}{ Heme synthesis enzymes } \\
\hline \multirow{5}{*}{ Ferrochelatase } & Teng et al., 2011 [76] & $\begin{array}{l}\text { Ferrochelatase mRNA is downregulated in glioblastoma tissue; glioma cells treated } \\
\text { with interference RNA showed enhanced PpIX fluorescence after 5-ALA exposure }\end{array}$ \\
\hline & Briel-Pump et al., 2018 [46] & $\begin{array}{l}\text { Medulloblastoma cell lines treated with 5-ALA had increased PpIX enhancement } \\
\text { associated with decreased ferrochelatase expression }\end{array}$ \\
\hline & Fukuhara et al., 2013 [37] & $\begin{array}{l}\text { Inhibition of ferrochelatase in human prostate cancer cell lines led to increased PpIX } \\
\text { accumulation after 5-ALA treatment; in vivo experiments showed increased } \\
\text { phototherapy-induced cell death after 5-ALA plus deferoxamine }\end{array}$ \\
\hline & Krieg et al., 2000 [36] & $\begin{array}{l}\text { Bladder carcinoma cell lines had decreased ferrochelatase and altered iron content } \\
\text { which may be regulators of fluorescence after 5-ALA treatment }\end{array}$ \\
\hline & $\begin{array}{l}\text { Van Hillegersberg et al., } \\
1992 \text { [77] }\end{array}$ & $\begin{array}{l}\text { Ferrochelatase activity is decreased 3-fold in a rat model of colon carcinoma liver } \\
\text { metastases compared to normal liver cells }\end{array}$ \\
\hline
\end{tabular}


Table 1. Cont.

\begin{tabular}{|c|c|c|}
\hline Potential Target & Supporting Literature & Findings \\
\hline Ferrochelatase & Berg et al., 1996 [47] & $\begin{array}{c}\text { Human adenocarcinoma and hamster fibroblast cell lines treated with iron chelators } \\
\text { plus 5-ALA showed increased PpIX accumulation and inhibition of ferrochelatase } \\
\text { activity }\end{array}$ \\
\hline \multirow{2}{*}{$\begin{array}{l}\text { Porphobilinogen } \\
\text { deaminase (PGDB) }\end{array}$} & Greenbaum et al., 2002 [42] & $\begin{array}{c}\text { A significant fraction of PGBD localizes to glioma cell nuclei following cellular } \\
\text { differentiation }\end{array}$ \\
\hline & Greenbaum et al., 2003 [43] & $\begin{array}{l}\text { In glioma cells PBGD interacts with RanBPM to induce cellular differentiation via } \\
\text { interactions with chromatin }\end{array}$ \\
\hline \multirow{2}{*}{ ALA-dehydratase (ALAD) } & $\begin{array}{l}\text { Hinnen et al., } 1998 \text { [39]; } \\
\text { Navone et al., } 1990 \text { [38] }\end{array}$ & $\begin{array}{l}\text { ALA-dehydratase and other heme synthesis enzyme activities are upregulated in } \\
\text { tumor cell lines compared to normal cells }\end{array}$ \\
\hline & Schauder et al., 2011 [40] & $\begin{array}{l}\text { Down-regulation of either ALAD or PGDB lead to increased activity of the other } \\
\text { enzyme and decreases in PpIX accumulation; both enzymes are important for 5-ALA } \\
\text { induced phototherapy }\end{array}$ \\
\hline \multicolumn{3}{|l|}{ Environmental factors } \\
\hline \multirow[b]{2}{*}{ Temperature } & Hirschberg et al., 2004 [78] & $\begin{array}{l}\text { Concurrent photodynamic therapy and hyperthermia }\left(40-46{ }^{\circ} \mathrm{C}\right) \text { produced a } \\
\text { synergistic effect in inducing apoptosis in glioma spheroids }\end{array}$ \\
\hline & Fisher et al., 2017 [79] & $\begin{array}{c}\text { Mild hypothermia }\left(34^{\circ} \mathrm{C}\right) \text { in a rat glioma model increased PpIX accumulation and } \\
\text { fluorescence, increased normal neuron survival after photodynamic therapy, and } \\
\text { extended animal lifespan }\end{array}$ \\
\hline $\mathrm{pH}$ & Collaud et al., 2004 [66] & PpIX formation is maximized in a slightly alkaline, but physiological $\mathrm{pH}$ of 7.4 \\
\hline \multirow{2}{*}{ Oxygen } & $\begin{array}{l}\text { Moan and Sommer, } 1985 \\
\text { [80] }\end{array}$ & $\begin{array}{c}\text { Decreased oxygen partial pressure reduced the efficacy of photodynamic therapy in } \\
\text { tumor cell lines }\end{array}$ \\
\hline & Albert et al., 2014 [81] & $\begin{array}{l}\text { 5-ALA-treated glioma cell lines in atmospheric oxygen conditions ( } \mathrm{pO} 2=19 \%) \\
\text { required less irradiation to kill compared to cell lines at physiological tumor } \\
\text { conditions }(\mathrm{pO} 2=9 \%)\end{array}$ \\
\hline
\end{tabular}

\subsection{Blood-Brain Barrier}

Gadolinium contrast-enhancement in malignant glioma is reliant on disruption of the $\mathrm{BBB}$ and is typically not reflected by infiltrating regions of the tumor margin [82]. However, PpIX has been shown to accumulate following 5-ALA administration in infiltrating glioma cells [68] and has been shown to be more sensitive for detecting active tumors than contrast or molecular imaging $[68,83]$. 5-ALA uptake in the CNS is believed to occur via protondependent peptide transporter 2 (PEPT2) and a putative $\mathrm{Na}^{+} / \mathrm{HCO}_{3}{ }^{-}$organic anion transporter in the choroid plexus [67]. PEPT2 helps transport oligopeptides and peptidelike molecules throughout the body and is an important driver of 5-ALA accumulation in non-glioma cancers alike $[84,85]$. Specifically, the $\mathrm{Na}^{+} / \mathrm{HCO}_{3}{ }^{-}$transporter may work to impact cellular $\mathrm{pH}$, thus decreasing 5-ALA accumulation via the proton-dependent PEPT2 channel [67]. PEPT2 levels tend to be increased in HGG compared to LGG [86]. Consistently, in an analysis of grade II and III gliomas, expression of mRNA encoding for PEPT2 was significantly higher in fluorescent tumors compared to non-fluorescent [87].

There is some evidence to suggest that the BBB plays a role in PpIX tumor selectivity in malignant glioma, specifically [33]. Several studies have shown that the intact BBB is relatively impermeable to 5-ALA, although liposomal encapsulation has been shown to facilitate transport and increase porphyrin concentration in the brain [70-72,75]. Further, it is known that PpIX accumulates within tumor tissue and areas without a defined BBB, such as the circumventricular organs [73]. As such, 5-ALA may selectively permeate the BBB in areas of tumoral neoangiogenesis or alterations to tumor cell transporter expression [88]. Malignant glioma is regarded as a "whole brain" disease, indicating that a clinically meaningful tumor burden is known to exist beyond what is identifiable on imaging $[8,86,87,89,90]$. Because of the migratory behavior of glioma cells, it is thus entirely possible that infiltrating tumor cells migrate away from the tumor center towards regions of comparatively more intact $\mathrm{BBB}$, hindering 5-ALA access to the entire tumor [91]. Although 
the integrity of the BBB is known to be compromised in malignant glioma, the extent of disruption is the subject of debate [89].

In LGG, there tends to be less BBB disruption compared to HGG, which may contribute to decreased 5-ALA permeability and uptake in the former class of tumors [92,93]. Nonetheless, there is 5-ALA uptake and consequent fluorescence in a significant minority of LGG, indicating other important mechanisms of 5-ALA uptake that are tumor-dependent. A few studies have pointed that the variation can exist even within a single tumor, and seems to depend on levels of cellular proliferation [94-96]. Further, some studies have shown that in non-fluorescent LGG, there is still some level of resultant PpIX accumulation that is undetectable macroscopically, but detectable through spectroscopy [97-99]. These studies suggest that accumulation of 5-ALA past the BBB may occur through multiple mechanisms simultaneously. Which of these mechanisms predominates is not clear.

\subsection{Tumor Microenvironmental Factors}

The effects of factors unique to the tumor microenvironment have been studied in the context of 5-ALA fluorescence and PpIX accumulation. Increased temperature can stimulate increased PpIX synthesis following 5-ALA administration, this is thought to be due to the fact that the rate limiting enzyme of heme synthesis (PBGD) almost doubles in efficiency at 45 over $37^{\circ} \mathrm{C}[66,78,100]$. Hypothermia has also been employed to protect surrounding normal brain tissue during photodynamic therapy. One study demonstrated that mild hypothermia $\left(34^{\circ} \mathrm{C}\right)$ leads to increased PpIX accumulation, tumor fluorescence, and survival after 5-ALA administration for photodynamic therapy in a rat glioma model, contrary to prior evidence [79]. Of note, angiogenesis, a hallmark of glioma tumorigenesis, is associated with hyperthermia in the tumor [101]. $\mathrm{pH}$ has also been shown to influence the production of PpIX in cells exposed to 5-ALA. PpIX production is maximal at $\mathrm{pH} 7.4$ and could be negatively affected by the acidic environment in which tumor cells reside [66]. Additionally, the photosensitizing effect of porphyrin derivatives in cancer cells has been shown to be oxygen dependent, an effect associated with reduced photodynamic therapy efficacy in hypoxic conditions [80,81]. Hypoxia is a hallmark of the tumor microenvironment for low- and high-grade gliomas alike. Finally, the physical microenvironment might contribute to PpIX synthesis, with one study by Niu et al. reporting higher concentrations of PpIX in glioma cells cultured on tissue-simulating gels than on stiffer tissue culture plastic [102].

\section{Photodynamic Therapy}

The principle of photodynamic therapy involves treatment with a photosensitizing compound that accumulates in a target tissue, followed by photoactivation. Photoactivation entails irradiation of the target tissue with a specified wavelength of light that catalyzes ROS production by acting on the accumulated photosensitizing compound [66]. The first step of PDT is administration of the photosensitizing compound by either venous injection or topical application depending on its intended use. After a lag period which allows for the photosensitizing agent to accumulate in the target tissues (e.g., cancer cells), light of a specific wavelength is applied to the desired area, and activation of the compound occurs, leading to local tissue destruction via ROS $[103,104]$. The advent of PDT dates back to early 20th century Germany and evolved to seminal experiments in the mid-20th century.

Hematoporphyrin was shown to be useful for tumor detection in 1960, and in 1978 Dougherty et al. demonstrated the clinical efficacy of hematoporphyrin-based PDT in several diverse cancers, including mycosis fungoides, angiosarcoma, and chondrosarcoma [105]. Since then, its clinical applications have expanded broadly. PDT today is most commonly known for its use in treating the dermatological condition actinic keratosis, and it has also shown efficacy in treatment of squamous cell carcinoma in situ and basal cell carcinoma, as well as severe acne and inflammatory conditions such as psoriasis, cutaneous sarcoidosis, and lichen planus $[103,106,107]$. In treatment of premalignant conditions and cancer, PDT has been utilized for Barrett's esophagus, esophageal carcinoma, cervical 
cancer, head and neck cancer, prostate cancer (targeting vasculature), lung cancer, bladder cancer, and peritoneal cancer, among others $[106,108]$. Exploration of PDT as combinatorial therapy with chemotherapy, immunotherapy, and radiotherapy has shown survival benefits and quality of life improvement in treating cancer as well [109].

In malignant gliomas, PDT has been administered via stereotactic navigation to augment 5-ALA activation and associated cytotoxicity, with some retrospective evidence to suggest a benefit $[110,111]$. The dual effect of 5-ALA intraoperative fluorescence and photodynamic therapy has been explored as a combinatorial strategy for the treatment of glioma [110]. 5-ALA administration has allowed for improved visualization of tumors intraoperatively and improves survival in glioma patients undergoing surgical resection [45,112].

\subsection{Cytotoxic Mechanisms}

Several cytotoxic mechanisms have been described in the setting of PDT, including autophagy, apoptosis, necrosis, necroptosis, and paraptosis [113]. At lower doses, it is thought that cell survival pathways may be activated, namely autophagy. However, at higher doses of ROS, apoptosis occurs. One study describing mechanisms of apoptosis associated with 5-ALA PDT reported an increased Bax:Bcl-2 ratio and mitochondrial release of cytochrome c and apoptosis-inducing factor in U87MG GBM cells [114]. A similar study found that ALA-DT induces apoptosis via increased activity of caspase-3 and -9, increased cytochrome c, as well as decreased mitochondrial membrane potential [115]. Another study identified 5-ALA induction of receptor-interacting protein 3, a known mediator of caspase-independent apoptosis. There is also evidence to suggest that 5-ALA PDT destroys vascular endothelial cells, indirectly contributing to tumor necrosis by disrupting blood flow [116]. 5-ALA has also been reported to act as a radiosensitizer, enhancing ionizing irradiation-induced mitochondrial oxidative stress and cell death [117]. Altogether, the cell death mechanisms initiated by PDT are multifactorial and influenced by a unique mixture of programmed cell death via apoptosis as well as necrosis due to cellular injury.

\subsection{5-ALA PDT Immune Effects}

With the exception of immunotherapies, radiotherapy and most chemotherapeutics have a net immunosuppressive effect, secondary in part to myelosuppression [118]. On the other hand, PDT is known to induce profound inflammatory effects on tumor cells. The release of heat-shock protein 70 in response to PDT is one of the most important factors in developing an immune response [118]. Specifically, these proteins form complexes with tumor antigens that are presented by antigen-presenting cells to stimulate an anti-tumor immune response [119]. In G422 murine glioma models, it has been shown that PDT increases the ratio of CD4+/CD8+ lymphocytes and promotes TNF- $\alpha$ and IFN- $\gamma$ release and promotes an anti-glioma response mediated by complement C3 and T-cells [120]. Additionally, 5-ALA has been shown to accumulate in macrophages and suppress prostaglandin $\mathrm{E}_{2}$ production by downregulating cyclooxygenase-2 and microsomal prostaglandin E synthase-1 expression [121].

\section{Conclusions}

The use of 5-ALA for fluorescence-guided resection of malignant brain tumors has become well accepted and a routine part of clinical care in many centers. However, the molecular and metabolic mechanisms that govern the specific and differential tumor tissue fluorescence triggered by 5-ALA administration are still incompletely understood. In recent years, attempts to elucidate these mechanisms have provided new insights into the role of the heme biosynthesis pathway in both the accumulation of PpIX and in glioma biology. There are numerous steps in the 5-ALA metabolism pathway that could be targeted to modulate PpIX accumulation and, by extension, glioma tissue fluorescence. Further investigation of this pathway may facilitate deeper understanding of high-grade glioma metabolism and biology. 
Author Contributions: S.K.M., K.G.A. contributed to study conception. All authors performed literature review and analysis. J.I.T., M.N.P., A.C.S. drafted the manuscript, figures, and tables. All authors have read and agreed to the published version of the manuscript.

Funding: This research was funded by Cancer Prevention and Research Institute of Texas grant number RR190034 and National Cancer Institute grant number K22CA237752, both awarded to S.K.M.

Acknowledgments: The authors would like to thank Melissa Logies for her illustration of the included figure.

Conflicts of Interest: K.G.A. is a compensated consultant for NX-Development Corporation. All other authors have no conflicts of interest to report.

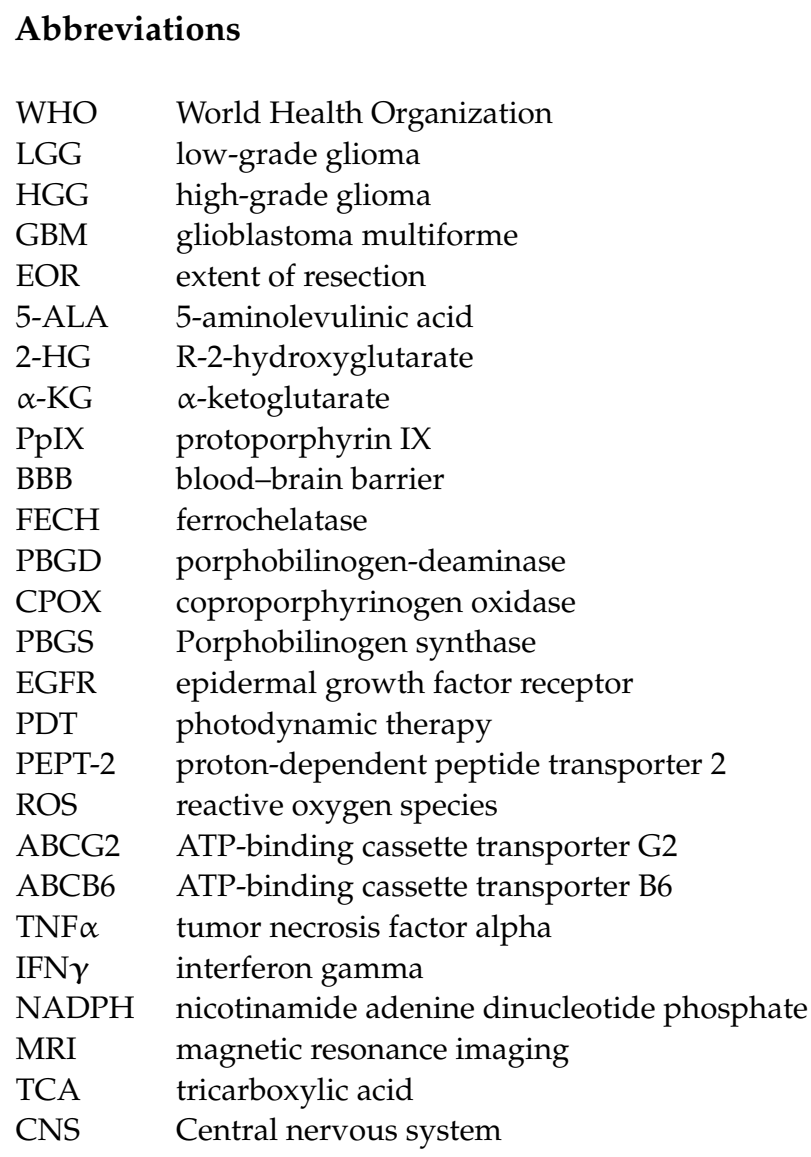

\section{References}

1. Louis, D.N.; Perry, A.; Reifenberger, G.; von Deimling, A.; Figarella-Branger, D.; Cavenee, W.K.; Ohgaki, H.; Wiestler, O.D.; Kleihues, P.; Ellison, D.W. The 2016 World Health Organization Classification of Tumors of the Central Nervous System: A summary. Acta Neuropathol. 2016, 131, 803-820. [CrossRef]

2. Stupp, R.; Mason, W.P.; Van Den Bent, M.J.; Weller, M.; Fisher, B.; Taphoorn, M.J.B.; Belanger, K.; Brandes, A.A.; Marosi, C.; Bogdahn, U.; et al. Radiotherapy plus concomitant and adjuvant temozolomide for glioblastoma. N. Engl. J. Med. 2005, 352, 987-996. [CrossRef] [PubMed]

3. McGirt, M.J.; Chaichana, K.L.; Gathinji, M.; Attenello, F.J.; Than, K.; Olivi, A.; Weingart, J.D.; Brem, H.; Quiñones-Hinojosa, A. Independent association of extent of resection with survival in patients with malignant brain astrocytoma: Clinical article. $J$. Neurosurg. 2009, 110, 156-162. [CrossRef] [PubMed]

4. Sanai, N.; Polley, M.Y.; McDermott, M.W.; Parsa, A.T.; Berger, M.S. An extent of resection threshold for newly diagnosed glioblastomas: Clinical article. J. Neurosurg. 2011, 115, 3-8. [CrossRef] [PubMed]

5. Stummer, W.; Pichlmeier, U.; Meinel, T.; Wiestler, O.D.; Zanella, F.; Reulen, H.J. Fluorescence-guided surgery with 5-aminolevulinic acid for resection of malignant glioma: A randomised controlled multicentre phase III trial. Lancet Oncol. 2006, 7, 392-401. [CrossRef]

6. Stummer, W.; Reulen, H.J.; Meinel, T.; Pichlmeier, U.; Schumacher, W.; Tonn, J.C.; Rohde, V.; Oppel, F.; Turowski, B.; Woiciechowsky, C.; et al. Extent of resection and survival in glioblastoma multiforme: Identification of and adjustment for bias. Neurosurgery 2008, 62, 564-574. [CrossRef] 
7. Stummer, W.; Van Den Bent, M.J.; Westphal, M. Cytoreductive surgery of glioblastoma as the key to successful adjuvant therapies: New arguments in an old discussion. Acta Neurochir. (Wien.) 2011, 153, 1211-1218. [CrossRef]

8. Molinaro, A.M.; Hervey-Jumper, S.; Morshed, R.A.; Young, J.; Han, S.J.; Chunduru, P.; Zhang, Y.; Phillips, J.J.; Shai, A.; Lafontaine, M.; et al. Association of Maximal Extent of Resection of Contrast-Enhanced and Non-Contrast-Enhanced Tumor with Survival Within Molecular Subgroups of Patients with Newly Diagnosed Glioblastoma. JAMA Oncol. 2020, 6, 495-503. [CrossRef]

9. Xia, L.; Fang, C.; Chen, G.; Sun, C. Relationship between the extent of resection and the survival of patients with low-grade gliomas: A systematic review and meta-analysis. BMC Cancer 2018, 18, 48. [CrossRef]

10. Shaw, E.; Arusell, R.; Scheithauer, B.; O’Fallon, J.; O’Neill, B.; Dinapoli, R.; Nelson, D.; Earle, J.; Jones, C.; Cascino, T.; et al. Prospective randomized trial of low-versus high-dose radiation therapy in adults with supratentorial low-grade glioma: Initial report of a North Central Cancer Treatment Group/Radiation Therapy Oncology Group/Eastern Cooperative Oncology Group Study. J. Clin. Oncol. 2002, 20, 2267-2276. [CrossRef]

11. Claes, A.; Idema, A.J.; Wesseling, P. Diffuse glioma growth: A guerilla war. Acta Neuropathol. 2007, 114, 443-458. [CrossRef]

12. Jaber, M.; Ewelt, C.; Wölfer, J.; Brokinkel, B.; Thomas, C.; Hasselblatt, M.; Grauer, O.; Stummer, W. Is Visible Aminolevulinic Acid-Induced Fluorescence an Independent Biomarker for Prognosis in Histologically Confirmed (World Health Organization 2016) Low-Grade Gliomas? Neurosurgery 2018, 84, 1214-1224. [CrossRef] [PubMed]

13. Stummer, W.; Tonn, J.C.; Goetz, C.; Ullrich, W.; Stepp, H.; Bink, A.; Pietsch, T.; Pichlmeier, U. 5-Aminolevulinic acid-derived tumor fluorescence: The diagnostic accuracy of visible fluorescence qualities as corroborated by spectrometry and histology and postoperative imaging. Neurosurgery 2014, 74, 310-319. [CrossRef] [PubMed]

14. Kiesel, B.; Millesi, M.; Woehrer, A.; Furtner, J.; Bavand, A.; Roetzer, T.; Mischkulnig, M.; Wolfsberger, S.; Preusser, M.; Knosp, E.; et al. 5-ALA-induced fluorescence as a marker for diagnostic tissue in stereotactic biopsies of intracranial lymphomas: Experience in 41 patients. Neurosurg. Focus 2018, 44. [CrossRef] [PubMed]

15. Kamp, M.A.; Fischer, I.; Bühner, J.; Turowski, B.; Cornelius, J.F.; Steiger, H.J.; Rapp, M.; Slotty, P.J.; Sabel, M. 5-ALA fluorescence of cerebral metastases and its impact for the local-in-brain progression. Oncotarget 2016, 7, 66776-66789. [CrossRef]

16. Kitada, M.; Ohsaki, Y.; Yasuda, S.; Abe, M.; Takahashi, N.; Okazaki, S.; Ishibashi, K.; Hayashi, S. Photodynamic diagnosis of visceral pleural invasion of lung cancer with a combination of 5-aminolevulinic acid and autofluorescence observation systems. Photodiagnosis Photodyn. Ther. 2017, 20, 10-15. [CrossRef]

17. Ishizuka, M.; Abe, F.; Sano, Y.; Takahashi, K.; Inoue, K.; Nakajima, M.; Kohda, T.; Komatsu, N.; Ogura, S.I.; Tanaka, T. Novel development of 5-aminolevurinic acid (ALA) in cancer diagnoses and therapy. Int. Immunopharmacol. 2011, 11, 358-365. [CrossRef]

18. Liberati, A.; Altman, D.G.; Tetzlaff, J.; Mulrow, C.; Gøtzsche, P.C.; Ioannidis, J.P.A.; Clarke, M.; Devereaux, P.J.; Kleijnen, J.; Moher, D. The PRISMA statement for reporting systematic reviews and meta-analyses of studies that evaluate healthcare interventions: Explanation and elaboration. BMJ 2009, 339. [CrossRef]

19. Markwardt, N.A.; Haj-Hosseini, N.; Hollnburger, B.; Stepp, H.; Zelenkov, P.; Rühm, A. 405 nm versus 633 nm for protoporphyrin IX excitation in fluorescence-guided stereotactic biopsy of brain tumors. J. Biophotonics 2016, 9, 901-912. [CrossRef]

20. Kriegmair, M.; Baumgartner, R.; Knüchel, R.; Stepp, H.; Hofstädter, F.; Hofstetter, A. Detection of early bladder cancer by 5-aminolevulinic acid induced porphyrin fluorescence. J. Urol. 1996, 155, 105-110. [CrossRef]

21. Fritsch, C.; Becker-Wegerich, P.M.; Schulte, K.W.; Neuse, W.; Lehmann, P.; Ruzicka, T.; Goerz, G. Photodynamische therapie und mamillenplastik eines grossflachigen rumpfhautbasalioms der mama. effektive kombinationstherapie unter photodynamischer diagnostik. Hautarzt 1996, 47, 438-442. [CrossRef]

22. Regula, J.; MacRobert, A.J.; Gorchein, A.; Buonaccorsi, G.A.; Thorpe, S.M.; Spencer, G.M.; Hatfield, A.R.W.; Bown, S.G. Photosensitisation and photodynamic therapy of oesophageal, duodenal, and colorectal tumours using 5 aminolaevulinic acid induced protoporphyrin IX-a pilot study. Gut 1995, 36, 67-75. [CrossRef] [PubMed]

23. Yang, P.; Liu, W.; Cheng, X.; Wang, J.; Wang, Q.; Qi, Q. A new strategy for production of 5-aminolevulinic acid in recombinant Corynebacterium glutamicum with high yield. Appl. Environ. Microbiol. 2016, 82, 2709-2717. [CrossRef] [PubMed]

24. Stummer, W.; Stocker, S.; Wagner, S.; Stepp, H.; Fritsch, C.; Goetz, C.; Goetz, A.E.; Kiefmann, R.; Reulen, H.J. Intraoperative detection of malignant gliomas by 5-aminolevulinic acid-induced porphyrin fluorescence. Neurosurgery 1998, 42, 518-526. [CrossRef] [PubMed]

25. Stummer, W.; Tonn, J.C.; Mehdorn, H.M.; Nestler, U.; Franz, K.; Goetz, C.; Bink, A.; Pichlmeier, U. Counterbalancing risks and gains from extended resections in malignant glioma surgery: A supplemental analysis from the randomized 5-aminolevulinic acid glioma resection study: Clinical article. J. Neurosurg. 2011, 114, 613-623. [CrossRef]

26. Hadjipanayis, C.G.; Stummer, W. 5-ALA and FDA approval for glioma surgery. J. Neurooncol. 2019, 141, 479-486. [CrossRef]

27. Nabavi, A.; Thurm, H.; Zountsas, B.; Pietsch, T.; Lanfermann, H.; Pichlmeier, U.; Mehdorn, M. Five-aminolevulinic acid for fluorescence-guided resection of recurrent malignant gliomas: A phase II study. Neurosurgery 2009, 65, 1070-1076. [CrossRef] [PubMed]

28. Han, K.; Ren, M.; Wick, W.; Abrey, L.; Das, A.; Jin, J.; Reardon, D.A. Progression-free survival as a surrogate endpoint for overall survival in glioblastoma: A literature-based meta-analysis from 91 trials. Neuro. Oncol. 2014, 16, 696-706. [CrossRef]

29. Drug Approval Package: Gleolan (Aminolevulinic Acid Hydrochloride). Available online: https://www.accessdata.fda.gov / drugsatfda_docs/nda/2017/208630Orig1s000TOC.cfm (accessed on 10 November 2020). 
30. Grant, W.E.; MacRobert, A.; Bown, S.G.; Hopper, C.; Speight, P.M. Photodynamic therapy of oral cancer: Photosensitisation with systemic aminolaevulinic acid. Lancet 1993, 342, 147-148. [CrossRef]

31. Berlin, N.I.; Neuberger, A.; Scott, J.J. The metabolism of $\delta$-aminolaevulic acid. 1 . Normal pathways, studied with the aid of $15 \mathrm{~N}$. Biochem. J. 1956, 64, 80-90. [CrossRef]

32. Kennedy, J.C.; Pottier, R.H. New trends in photobiology. Endogenous protoporphyrin IX, a clinically useful photosensitizer for photodynamic therapy. J. Photochem. Photobiol. B Biol. 1992, 14, 275-292. [CrossRef]

33. Stepp, H.; Stummer, W. Delineating normal from diseased brain by aminolevulinic acid-induced fluorescence. In Optical Methods and Instrumentation in Brain Imaging and Therapy; Springer: New York, NY, USA, 2013; pp. 173-205. ISBN 9781461449782.

34. Fratz, E.J.; Hunter, G.A.; Ferreira, G.C. Expression of murine 5-aminolevulinate synthase variants causes protoporphyrin IX accumulation and light-induced mammalian cell death. PLoS ONE 2014, 9, e93078. [CrossRef] [PubMed]

35. Krieg, R.C.; Messmann, H.; Rauch, J.; Seeger, S.; Knuechel, R. Metabolic Characterization of Tumor Cell-specific Protoporphyrin IX Accumulation After Exposure to 5-Aminolevulinic Acid in Human Colonic Cells. Photochem. Photobiol. 2002, 76, 518-525. [CrossRef]

36. Krieg, R.C.; Fickweiler, S.; Wolfbeis, O.S.; Knuechel, R. Cell-type Specific Protoporphyrin IX Metabolism in Human Bladder Cancer in vitro. Photochem. Photobiol. 2000, 72, 226-233. [CrossRef]

37. Fukuhara, H.; Inoue, K.; Kurabayashi, A.; Furihata, M.; Fujita, H.; Utsumi, K.; Sasaki, J.; Shuin, T. The inhibition of ferrochelatase enhances 5-aminolevulinic acid-based photodynamic action for prostate cancer. Photodiagnosis Photodyn. Ther. 2013, 10, 399-409. [CrossRef]

38. Navone, N.M.; Polo, C.F.; Frisardi, A.L.; Andrade, N.E.; Alcira, A.M. Heme biosynthesis in human breast cancer-mimetic "in vitro" studies and some heme enzymic activity levels. Int. J. Biochem. 1990, 22, 1407-1411. [CrossRef]

39. Hinnen, P.; De Rooij, F.W.M.; Van Velthuysen, M.L.F.; Edixhoven, A.; Van Hillegersberg, R.; Tilanus, H.W.; Wilson, J.H.P.; Siersema, P.D. Biochemical basis of 5-aminolaevulinic acid-induced protoporphyrin IX accumulation: A study in patients with (pre)malignant lesions of the oesophagus. Br. J. Cancer 1998, 78, 679-682. [CrossRef]

40. Schauder, A.; Feuerstein, T.; Malik, Z. The centrality of PBGD expression levels on ALA-PDT efficacy. Photochem. Photobiol. Sci. 2011, 10, 1310-1317. [CrossRef]

41. Auer, R.N.; Maestro, R.F.D.; Anderson, R. A Simple and Reproducible Experimental in Vivo Glioma Model. Can. J. Neurol. Sci./J. Can. Sci. Neurol. 1981, 8, 325-331. [CrossRef]

42. Greenbaum, L.; Gozlan, Y.; Schwartz, D.; Katcoff, D.J.; Malik, Z. Nuclear distribution of porphobilinogen deaminase (PBGD) in glioma cells: A regulatory role in cancer transformation? Br. J. Cancer 2002, 86, 1006-1011. [CrossRef]

43. Greenbaum, L.; Katcoff, D.J.; Dou, H.; Gozlan, Y.; Malik, Z. A porphobilinogen deaminase (PBGD) Ran-binding protein interaction is implicated in nuclear trafficking of PBGD in differentiating glioma cells. Oncogene 2003, 22, 5221-5228. [CrossRef] [PubMed]

44. Pustogarov, N.; Panteleev, D.; Goryaynov, S.A.; Ryabova, A.V.; Rybalkina, E.Y.; Revishchin, A.; Potapov, A.A.; Pavlova, G. Hiding in the Shadows: CPOX Expression and 5-ALA Induced Fluorescence in Human Glioma Cells. Mol. Neurobiol. 2017, 54, 5699-5708. [CrossRef]

45. Stepp, H.; Stummer, W. 5-ALA in the management of malignant glioma. Lasers Surg. Med. 2018, 50, 399-419. [CrossRef] [PubMed]

46. Briel-Pump, A.; Beez, T.; Ebbert, L.; Remke, M.; Weinhold, S.; Sabel, M.C.; Sorg, R.V. Accumulation of protoporphyrin IX in medulloblastoma cell lines and sensitivity to subsequent photodynamic treatment. J. Photochem. Photobiol. B Biol. 2018, 189, 298-305. [CrossRef] [PubMed]

47. Berg, K.; Anholt, H.; Bech, O.; Moan, J. The influence of iron chelators on the accumulation of protoporphyrin IX in 5aminolaevulinic acid-treated cells. Br. J. Cancer 1996, 74, 688-697. [CrossRef] [PubMed]

48. Wang, W.; Tabu, K.; Hagiya, Y.; Sugiyama, Y.; Kokubu, Y.; Murota, Y.; Ogura, S.I.; Taga, T. Enhancement of 5-aminolevulinic acid-based fluorescence detection of side population-defined glioma stem cells by iron chelation. Sci. Rep. 2017, 7. [CrossRef]

49. Blake, E.; Allen, J.; Curnow, A. An in vitro comparison of the effects of the iron-chelating agents, CP94 and dexrazoxane, on protoporphyrin IX accumulation for photodynamic therapy and/or fluorescence guided resection. Photochem. Photobiol. 2011, 87, 1419-1426. [CrossRef]

50. Blake, E.; Curnow, A. The hydroxypyridinone iron chelator CP94 can enhance PpIX-induced PDT of cultured human glioma cells. Photochem. Photobiol. 2010, 86, 1154-1160. [CrossRef]

51. Sinha, A.K.; Anand, S.; Ortel, B.J.; Chang, Y.; Mai, Z.; Hasan, T.; Maytin, E.V. Methotrexate used in combination with aminolaevulinic acid for photodynamic killing of prostate cancer cells. Br. J. Cancer 2006, 95, 485-495. [CrossRef]

52. Park, N.I.; Guilhamon, P.; Desai, K.; McAdam, R.F.; Langille, E.; O'Connor, M.; Lan, X.; Whetstone, H.; Coutinho, F.J.; Vanner, R.J.; et al. ASCL1 Reorganizes Chromatin to Direct Neuronal Fate and Suppress Tumorigenicity of Glioblastoma Stem Cells. Cell Stem Cell 2017, 21, 209-224.e7. [CrossRef]

53. Kim, J.E.; Cho, H.R.; Xu, W.J.; Kim, J.Y.; Kim, S.K.; Kim, S.K.; Park, S.H.; Kim, H.; Lee, S.H.; Choi, S.H.; et al. Mechanism for enhanced 5-aminolevulinic acid fluorescence in isocitrate dehydrogenase 1 mutant malignant gliomas. Oncotarget 2015, 6, 20266-20277. [CrossRef] [PubMed]

54. Badur, M.G.; Muthusamy, T.; Parker, S.J.; Ma, S.; McBrayer, S.K.; Cordes, T.; Magana, J.H.; Guan, K.L.; Metallo, C.M. Oncogenic R132 IDH1 Mutations Limit NADPH for De Novo Lipogenesis through (D)2-Hydroxyglutarate Production in Fibrosarcoma Cells. Cell Rep. 2018, 25, 1018-1026.e4. [CrossRef] [PubMed] 
55. Dang, L.; White, D.W.; Gross, S.; Bennett, B.D.; Bittinger, M.A.; Driggers, E.M.; Fantin, V.R.; Jang, H.G.; Jin, S.; Keenan, M.C.; et al. Cancer-associated IDH1 mutations produce 2-hydroxyglutarate. Nature 2009, 462, 739-744. [CrossRef] [PubMed]

56. Kim, S.; Kim, J.E.; Kim, Y.H.; Hwang, T.; Kim, S.K.; Xu, W.J.; Shin, J.Y.; Kim, J.I.; Choi, H.; Kim, H.C.; et al. Glutaminase 2 expression is associated with regional heterogeneity of 5-aminolevulinic acid fluorescence in glioblastoma. Sci. Rep. 2017, 7, 1-11. [CrossRef]

57. Yang, X.; Li, W.; Palasuberniam, P.; Myers, K.A.; Wang, C.; Chen, B. Effects of Silencing Heme Biosynthesis Enzymes on 5-Aminolevulinic Acid-mediated Protoporphyrin IX Fluorescence and Photodynamic Therapy. Photochem. Photobiol. 2015, 91, 923-930. [CrossRef]

58. Ogino, T.; Kobuchi, H.; Munetomo, K.; Fujita, H.; Yamamoto, M.; Utsumi, T.; Inoue, K.; Shuin, T.; Sasaki, J.; Inoue, M.; et al. Serum-dependent export of protoporphyrin IX by ATP-binding cassette transporter G2 in T24 cells. Mol. Cell. Biochem. 2011, 358, 297-307. [CrossRef]

59. Mesenhöller, M.; Matthews, E.K. A key role for the mitochondrial benzodiazepine receptor in cellular photosensitisation with $\delta$-aminolaevulinic acid. Eur. J. Pharmacol. 2000, 406, 171-180. [CrossRef]

60. Bisland, S.K.; Goebel, E.A.; Hassanali, N.S.; Johnson, C.; Wilson, B.C. Increased expression of mitochondrial benzodiazepine receptors following low-level light treatment facilitates enhanced protoporphyrin IX production in glioma-derived cells in vitro. Lasers Surg. Med. 2007, 39, 678-684. [CrossRef]

61. Oberstadt, M.C.; Bien-Möller, S.; Weitmann, K.; Herzog, S.; Hentschel, K.; Rimmbach, C.; Vogelgesang, S.; Balz, E.; Fink, M.; Michael, H.; et al. Epigenetic modulation of the drug resistance genes MGMT, ABCB1 and ABCG2 in glioblastoma multiforme. BMC Cancer 2013, 13. [CrossRef]

62. Kawai, N.; Hirohashi, Y.; Ebihara, Y.; Saito, T.; Murai, A.; Saito, T.; Shirosaki, T.; Kubo, T.; Nakatsugawa, M.; Kanaseki, T.; et al. ABCG2 expression is related to low 5-ALA photodynamic diagnosis (PDD) efficacy and cancer stem cell phenotype, and suppression of ABCG2 improves the efficacy of PDD. PLOS ONE 2019, 14, e216503. [CrossRef]

63. Zhao, S.G.; Chen, X.F.; Wang, L.G.; Yang, G.; Han, D.Y.; Teng, L.; Yang, M.C.; Wang, D.Y.; Shi, C.; Liu, Y.H.; et al. Increased expression of ABCB6 enhances protoporphyrin ix accumulation and photodynamic effect in human glioma. Ann. Surg. Oncol. 2013, 20, 4379-4388. [CrossRef] [PubMed]

64. Fontana, A.O.; Piffaretti, D.; Marchi, F.; Burgio, F.; Faia-Torres, A.B.; Paganetti, P.; Pinton, S.; Pieles, U.; Reinert, M. Epithelial growth factor receptor expression influences 5-ALA induced glioblastoma fluorescence. J. Neurooncol. 2017, 133, 497-507. [CrossRef] [PubMed]

65. Wyld, L.; Burn, J.L.; Reed, M.W.R.; Brown, N.J. Factors affecting aminolaevulinic acid-induced generation of protoporphyrin IX. Br. J. Cancer 1997, 76, 705-712. [CrossRef] [PubMed]

66. Collaud, S.; Juzeniene, A.; Moan, J.; Lange, N. On the selectivity of 5-aminolevulinic acid-induced protoporphyrin IX formation. Curr. Med. Chem. Anti-Cancer Agents 2004, 4, 301-316. [CrossRef] [PubMed]

67. Novotny, A.; Xiang, J.; Stummer, W.; Teuscher, N.S.; Smith, D.E.; Keep, R.F. Mechanisms of 5-aminolevulinic acid uptake at the choroid plexus. J. Neurochem. 2000, 75, 321-328. [CrossRef] [PubMed]

68. Utsuki, S.; Oka, H.; Sato, S.; Suzuki, S.; Shimizu, S.; Tanaka, S.; Fujii, K. Possibility of using laser spectroscopy for the intraoperative detection of nonfluorescing brain tumors and the boundaries of brain tumor infiltrates: Technical note. J. Neurosurg. 2006, 104, 618-620. [CrossRef] [PubMed]

69. Ennis, S.R.; Novotny, A.; Xiang, J.; Shakui, P.; Masada, T.; Stummer, W.; Smith, D.E.; Keep, R.F. Transport of 5-aminolevulinic acid between blood and brain. Brain Res. 2003, 959, 226-234. [CrossRef]

70. García, S.C.; Moretti, M.B.; Garay, M.V.R.; Batlle, A. $\delta$-Aminolevulinic acid transport through blood-brain barrier. Gen. Pharmacol. 1998, 31, 579-582. [CrossRef]

71. Malakoutikhah, M.; Pradesh, R.; Teixidó, M.; Giralt, E. N-Methyl Phenylalanine-Rich peptides as highly versatile blood-brain barrier shuttles. J. Med. Chem. 2010, 53, 2354-2363. [CrossRef]

72. Terr, L.; Weiner, L.P. An autoradiographic study of $\delta$-aminolevulinic acid uptake by mouse brain. Exp. Neurol. 1983, 79, 564-568. [CrossRef]

73. Olivo, M.; Wilson, C.B. Mapping ALA-induced PPIX fluorescence in normal brain and brain tumour using confocal fluorescence microscopy. Int. J. Oncol. 2004, 25, 37-45. [CrossRef] [PubMed]

74. Molina, E.J.S.; Ardon, H.; Schroeteler, J.; Klingenhöfer, M.; Holling, M.; Wölfer, J.; Fischer, B.; Stummer, W.; Ewelt, C. Aquaporin-4 in glioma and metastatic tissues harboring 5-aminolevulinic acid-induced porphyrin fluorescence. Clin. Neurol. Neurosurg. 2013, 115, 2075-2081. [CrossRef] [PubMed]

75. Fukuda, H.; Paredes, S.; Batlle, A.M. Tumour-localizing properties of porphyrins. In vivo studies using free and liposome encapsulated aminolevulinic acid. Comp. Biochem. Physiol. Part. B Biochem. 1992, 102, 433-436. [CrossRef]

76. Teng, L.; Nakada, M.; Zhao, S.G.; Endo, Y.; Furuyama, N.; Nambu, E.; Pyko, I.V.; Hayashi, Y.; Hamada, J.I. Silencing of ferrochelatase enhances 5-aminolevulinic acid-based fluorescence and photodynamic therapy efficacy. Br. J. Cancer 2011, 104, 798-807. [CrossRef] [PubMed]

77. Van Hillegersberg, R.; Van Den Berg, J.W.O.; Kort, W.J.; Terpstra, O.T.; Wilson, J.H.P. Selective accumulation of endogenously produced porphyrins in a liver metastasis model in rats. Gastroenterology 1992, 103, 647-651. [CrossRef]

78. Hirschberg, H.; Sun, C.H.; Tromberg, B.J.; Yeh, A.T.; Madsen, S.J. Enhanced cytotoxic effects of 5-aminolevulinic acid-mediated photodynamic therapy by concurrent hyperthermia in glioma spheroids. J. Neurooncol. 2004, 70, 289-299. [CrossRef] [PubMed] 
79. Fisher, C.J.; Niu, C.; Foltz, W.; Chen, Y.; Sidorova-Darmos, E.; Eubanks, J.H.; Lilge, L. ALA-PpIX mediated photodynamic therapy of malignant gliomas augmented by hypothermia. PLoS ONE 2017, 12, e181654. [CrossRef] [PubMed]

80. Moan, J.; Sommer, S. Oxygen Dependence of the Photosensitizing Effect of Hematoporphyrin Derivative in NHIK 3025 Cells. Cancer Res. 1985, 45, 1608-1610.

81. Albert, I.; Hefti, M.; Luginbuehl, V. Physiological oxygen concentration alters glioma cell malignancy and responsiveness to photodynamic therapy in vitro. Neurol. Res. 2014, 36, 1001-1010. [CrossRef]

82. Arbizu, J.; Tejada, S.; Marti-Climent, J.M.; Diez-Valle, R.; Prieto, E.; Quincoces, G.; Vigil, C.; Idoate, M.A.; Zubieta, J.L.; Peñuelas, I.; et al. Quantitative volumetric analysis of gliomas with sequential MRI and 11C-methionine PET assessment: Patterns of integration in therapy planning. Eur. J. Nucl. Med. Mol. Imaging 2012, 39, 771-781. [CrossRef]

83. Roessler, K.; Becherer, A.; Donat, M.; Cejna, M.; Zachenhofer, I. Intraoperative tissue fluorescence using 5- aminolevolinic acid (5-ALA) is more sensitive than contrast MRI or amino acid positron emission tomography (18F-FET PET) in glioblastoma surgery. Neurol. Res. 2012, 34, 314-317. [CrossRef] [PubMed]

84. Kamal, M.A.; Keep, R.F.; Smith, D.E. Role and relevance of PEPT2 in drug disposition, dynamics, and toxicity. Drug Metab. Pharmacokinet. 2008, 23, 236-242. [CrossRef] [PubMed]

85. Rodriguez, L.; Batlle, A.; Di Venosa, G.; MacRobert, A.J.; Battah, S.; Daniel, H.; Casas, A. Study of the mechanisms of uptake of 5-aminolevulinic acid derivatives by PEPT1 and PEPT2 transporters as a tool to improve photodynamic therapy of tumours. Int. J. Biochem. Cell Biol. 2006, 38, 1530-1539. [CrossRef] [PubMed]

86. Zimmermann, M.; Stan, A.C. PepT2 transporter protein expression in human neoplastic glial cells and mediation of fluorescently tagged dipeptide derivative $\beta$-Ala-Lys- $\mathrm{N}$ E-7-amino-4-methyl-coumarin-3-acetic acid accumulation: Laboratory investigation. J. Neurosurg. 2010, 112, 1005-1014. [CrossRef] [PubMed]

87. Hou, C.; Yamaguchi, S.; Ishi, Y.; Terasaka, S.; Kobayashi, H.; Motegi, H.; Hatanaka, K.C.; Houkin, K. Identification of PEPT2 as an important candidate molecule in 5-ALA-mediated fluorescence-guided surgery in WHO grade II/III gliomas. J. Neurooncol. 2019, 143, 197-206. [CrossRef]

88. Novotny, A.; Stummer, W. 5-Aminolevulinic acid and the blood-brain barrier-A review. Med. Laser Appl. 2003, 18, 36-40. [CrossRef]

89. Sarkaria, J.N.; Hu, L.S.; Parney, I.F.; Pafundi, D.H.; Brinkmann, D.H.; Laack, N.N.; Giannini, C.; Burns, T.C.; Kizilbash, S.H.; Laramy, J.K.; et al. Is the blood-brain barrier really disrupted in all glioblastomas? A critical assessment of existing clinical data. Neuro. Oncol. 2018, 20, 184-191. [CrossRef]

90. Agarwal, S.; Sane, R.; Oberoi, R.; Ohlfest, J.R.; Elmquist, W.F. Delivery of molecularly targeted therapy to malignant glioma, a disease of the whole brain. Expert Rev. Mol. Med. 2011, 13, e17. [CrossRef]

91. Plate, K.H.; Scholz, A.; Dumont, D.J. Tumor angiogenesis and anti-angiogenic therapy in malignant gliomas revisited. Acta Neuropathol. 2012, 124, 763-775. [CrossRef]

92. Provenzale, J.M.; Wang, G.R.; Brenner, T.; Petrella, J.R.; Sorensen, A.G. Comparison of permeability in high-grade and low-grade brain tumors using dynamic susceptibility contrast MR imaging. Am. J. Roentgenol. 2002, 178, 711-716. [CrossRef]

93. Li, X.; Zhu, Y.; Kang, H.; Zhang, Y.; Liang, H.; Wang, S.; Zhang, W. Glioma grading by microvascular permeability parameters derived from dynamic contrast-enhanced MRI and intratumoral susceptibility signal on susceptibility weighted imaging. Cancer Imaging 2015, 15, 1-9. [CrossRef] [PubMed]

94. Goryaynov, S.A.; Widhalm, G.; Goldberg, M.F.; Chelushkin, D.; Spallone, A.; Chernyshov, K.A.; Ryzhova, M.; Pavlova, G.; Revischin, A.; Shishkina, L.; et al. The role of 5-ALA in low-grade gliomas and the influence of antiepileptic drugs on intraoperative fluorescence. Front. Oncol. 2019, 9, 423. [CrossRef]

95. Valdés, P.A.; Jacobs, V.; Harris, B.T.; Wilson, B.C.; Leblond, F.; Paulsen, K.D.; Roberts, D.W. Quantitative fluorescence using 5-aminolevulinic acid-induced protoporphyrin IX biomarker as a surgical adjunct in low-grade glioma surgery. J. Neurosurg. 2015, 123, 771-780. [CrossRef] [PubMed]

96. Widhalm, G.; Kiesel, B.; Woehrer, A.; Traub-Weidinger, T.; Preusser, M.; Marosi, C.; Prayer, D.; Hainfellner, J.A.; Knosp, E.; Wolfsberger, S. 5-Aminolevulinic Acid Induced Fluorescence Is a Powerful Intraoperative Marker for Precise Histopathological Grading of Gliomas with Non-Significant Contrast-Enhancement. PLoS ONE 2013, 8, e76988. [CrossRef] [PubMed]

97. Widhalm, G.; Olson, J.; Weller, J.; Bravo, J.; Han, S.J.; Phillips, J.; Hervey-Jumper, S.L.; Chang, S.M.; Roberts, D.W.; Berger, M.S. The value of visible 5-ALA fluorescence and quantitative protoporphyrin IX analysis for improved surgery of suspected low-grade gliomas. J. Neurosurg. 2020, 133, 79-88. [CrossRef]

98. Valdés, P.A.; Kim, A.; Leblond, F.; Conde, O.M.; Harris, B.T.; Paulsen, K.D.; Wilson, B.C.; Roberts, D.W. Combined fluorescence and reflectance spectroscopy for in vivo quantification of cancer biomarkers in low- and high-grade glioma surgery. J. Biomed. Opt. 2011, 16, 116007. [CrossRef] [PubMed]

99. Ishihara, R.; Katayama, Y.; Watanabe, T.; Yoshino, A.; Fukushima, T.; Sakatani, K. Quantitative spectroscopic analysis of 5aminolevulinic acid-induced protoporphyrin IX fluorescence intensity in diffusely infiltrating astrocytomas. Neurol. Med. Chir. 2007, 47, 53-57. [CrossRef]

100. Anderson, P.M.; Desnick, R.J. Purification and properties of delta-aminolevulinate dehydrase from human erythrocytes. J. Biol. Chem. 1979, 254, 6924-6930. [CrossRef] 
101. Stefanadis, C.; Chrysochoou, C.; Markou, D.; Petraki, K.; Panagiotakos, D.B.; Fasoulakis, C.; Kyriakidis, A.; Papadimitriou, C.; Toutouzas, P.K. Increased temperature of malignant urinary bladder tumors in vivo: The application of a new method based on a catheter technique. J. Clin. Oncol. 2001, 19, 676-681. [CrossRef]

102. Niu, C.J.; Fisher, C.; Scheffler, K.; Wan, R.; Maleki, H.; Liu, H.; Sun, Y.; Simmons, C.A.A.; Birngruber, R.; Lilge, L. Polyacrylamide gel substrates that simulate the mechanical stiffness of normal and malignant neuronal tissues increase protoporphyin IX synthesis in glioma cells. J. Biomed. Opt. 2015, 20, 098002. [CrossRef]

103. Keyal, U.; Bhatta, A.K.; Wang, X.L. Photodynamic therapy for the treatment of different severity of acne: A systematic review. Photodiagnosis Photodyn. Ther. 2016, 14, 191-199. [CrossRef] [PubMed]

104. Dougherty, T.J.; Gomer, C.J.; Henderson, B.W.; Jori, G.; Kessel, D.; Korbelik, M.; Moan, J.; Peng, Q. Photodynamic therapy. J. Natl. Cancer Inst. 1998, 90, 889-905. [CrossRef] [PubMed]

105. Lipson, R.L.; Baldes, E.J.; Olsen, A.M. The use of a derivative of hematoporphyrin in tumor detection. J. Natl. Cancer Inst. 1961, 26, 1-11. [CrossRef] [PubMed]

106. Yanovsky, R.L.; Bartenstein, D.W.; Rogers, G.S.; Isakoff, S.J.; Chen, S.T. Photodynamic therapy for solid tumors: A review of the literature. Photodermatol. Photoimmunol. Photomed. 2019, 35, 295-303. [CrossRef]

107. Garretson, C.; Taub, A.F. Photodynamic Therapy and Inflammatory Disorders. In Photodynamic Therapy in Dermatology; Springer: New York, NY, USA, 2011; pp. 105-122.

108. Dolmans, D.E.J.G.J.; Fukumura, D.; Jain, R.K. Photodynamic therapy for cancer. Nat. Rev. Cancer 2003, 3, 380-387. [CrossRef]

109. Zhang, Q.; Li, L. Photodynamic combinational therapy in cancer treatment. JBUON 2018, 23, 561-567.

110. Schipmann, S.; Müther, M.; Stögbauer, L.; Zimmer, S.; Brokinkel, B.; Holling, M.; Grauer, O.; Suero Molina, E.; Warneke, N.; Stummer, W. Combination of ALA-induced fluorescence-guided resection and intraoperative open photodynamic therapy for recurrent glioblastoma: Case series on a promising dual strategy for local tumor control. J. Neurosurg. 2020, 1-11. [CrossRef]

111. Johansson, A.; Faber, F.; Kniebühler, G.; Stepp, H.; Sroka, R.; Egensperger, R.; Beyer, W.; Kreth, F.W. Protoporphyrin IX fluorescence and photobleaching during interstitial photodynamic therapy of malignant gliomas for early treatment prognosis. Lasers Surg. Med. 2013, 45, 225-234. [CrossRef]

112. Mahmoudi, K.; Garvey, K.L.; Bouras, A.; Cramer, G.; Stepp, H.; Jesu Raj, J.G.; Bozec, D.; Busch, T.M.; Hadjipanayis, C.G. 5-aminolevulinic acid photodynamic therapy for the treatment of high-grade gliomas. J. Neurooncol. 2019, 141, 595-607.

113. Kessel, D. Apoptosis, Paraptosis and Autophagy: Death and Survival Pathways Associated with Photodynamic Therapy. Photochem. Photobiol. 2019, 95, 119-125. [CrossRef]

114. Karmakar, S.; Banik, N.L.; Patel, S.J.; Ray, S.K. 5-Aminolevulinic acid-based photodynamic therapy suppressed survival factors and activated proteases for apoptosis in human glioblastoma U87MG cells. Neurosci. Lett. 2007, 415, 242-247. [CrossRef] [PubMed]

115. Inoue, H.; Kajimoto, Y.; Shibata, M.A.; Miyoshi, N.; Ogawa, N.; Miyatake, S.I.; Otsuki, Y.; Kuroiwa, T. Massive apoptotic cell death of human glioma cells via a mitochondrial pathway following 5-aminolevulinic acid-mediated photodynamic therapy. $J$. Neurooncol. 2007, 83, 223-231. [CrossRef] [PubMed]

116. Chang, C.J.; Sun, C.H.; Liaw, L.H.L.; Berns, M.W.; Nelson, J.S. In vitro and in vivo photosensitizing capabilities of 5-ALA versus Photofrin ${ }^{\circledR}$ in vascular endothelial cells. Lasers Surg. Med. 1999, 24, 178-186. [CrossRef]

117. Ueta, K.; Yamamoto, J.; Tanaka, T.; Nakano, Y.; Kitagawa, T.; Nishizawa, S. 5-Aminolevulinic acid enhances mitochondrial stress upon ionizing irradiation exposure and increases delayed production of reactive oxygen species and cell death in glioma cells. Int. J. Mol. Med. 2017, 39, 387-398. [CrossRef] [PubMed]

118. Castano, A.P.; Mroz, P.; Hamblin, M.R. Photodynamic therapy and anti-tumour immunity. Nat. Rev. Cancer 2006, 6, 535-545. [CrossRef]

119. Korbelik, M.; Sun, J.; Cecic, I. Photodynamic Therapy-Induced Cell Surface Expression and Release of Heat Shock Proteins: Relevance for Tumor Response. Cancer Res. 2005, 65, 1018-1026.

120. Li, F.; Cheng, Y.; Lu, J.; Hu, R.; Wan, Q.; Feng, H. Photodynamic therapy boosts anti-glioma immunity in mice: A dependence on the activities of T cells and complement C3. J. Cell. Biochem. 2011, 112, 3035-3043. [CrossRef]

121. Nakano, Y.; Kitagawa, T.; Osada, Y.; Tanaka, T.; Nishizawa, S.; Yamamoto, J. 5-Aminolevulinic Acid Suppresses Prostaglandin E2 Production by Murine Macrophages and Enhances Macrophage Cytotoxicity Against Glioma. World Neurosurg. 2019, 127, e669-e676. [CrossRef] 